\title{
First professional, in-service and continuing education and'training: provincial library staff perceptions
}

\author{
C. Stilwell \\ Department of Information Studies, University of Natal, Private Bag X01, Scottsville, 3209 Republic of South Africa \\ stilwell@infs.unp.ac.za
}

Received July 1997; accepted September 1997

\begin{abstract}
Changes in education and training are anticipated countrywide in terms of the National Qualifications Framework. This framework, based on a system of credits for achieved learning outcomes, is overseen by the South African Qualifications Authority, a parastatal body, which will assist professional bodies in the establishment of appropriate national standards through accrediting bodies. These developments focus attention on the Library and Information Service's sector's education and training debates. This article addresses issues of first professional, in-service and continuing education and training with particular reference to requirements reported by a large group of public library service providers, the profesionally qualified staff of the provincial library services.
\end{abstract}

Veranderinge in onderwys en opleiding word landswyd verwag in die lig van die Nasionale Kwalifikasie Raamwerk. Hierdie raamwerk wat gebaseer is op 'n stelsel van erkenning van verkreë leeruitkomstes staan onder die toesig van die Suid-Afrikaanse Kwalifikasie Raad, 'n parastatale liggaam wat professionele liggame sal bystaan in die vasstelling van geskikte nasionale standaarde deur akkrediteringsliggame. Hierdie ontwikkeling fokus die aandag op gesprekke rondom opleiding in die biblioteek- en inligtingsdienssektor. Die artikel spreek sake van belang vir professionele opleiding asook voortgesette indiensopleiding aan, met spesifieke verwysing na die behoeftes van die professionele personeel van provinsiale biblioteekdienste.

\section{Background and aim}

Leading up to changes anticipated in terms of the South African Qualifications Authority (SAQA) and the National Qualifications Framework (NQF), education and training, generally, and Library and Information Services (LIS), are under debate. Areas of particular contention are usefully identified by Underwood and Nassimbeni (1996:218-219): the distinction between types of qualification at first professional level; linkages between these respective programmes, that is which would allow first professional level technikon diplomates access to graduate programmes currently offered by universities; and the nature of the curriculum and its core subjects and varying emphases between library and information studies on the one hand and information science on the other. The lack of an agreed-upon and accredited system of modular courses limits the mobility of students wishing to move from one training institution to another. Other issues are cultural, class and language biases and the general absence of specialized training in rural library and information work.

There appears to have been little, or no discussion, however, about the education and training requirements of particular groupings of library personnel in specific library situations in South Africa. A useful view of the debates could be encouraged by perhaps inverting the problem and starting with the specific education and training requirements of particular groups in a bottom-up way, thereby arriving eventually at a core of first professional and other attributes and competencies required in library and information work situations. Forms of education and training and continuing education in particular have been seen as 'a means of uplifting and updating library and information personnel to cope with the changes that socio-political circumstances have brought in the country' (Kaniki 1997:1).

This article addresses the issue with reference to the education and training requirements reported by a large group of public library service providers, the professionally qualified staff of the provincial library services. These requirements are reported on after the definition of terms below. A doctoral study completed in 1995 investigated the research problem that an analysis of the perceptions of the staff of the structure of the provincial library services and their affiliated public libraries during the period 1990 to April 1994 would demonstrate a need on the part of public library providers for adaptation to changing socio-economic circumstances (Stilwell 1995). The study indicated needs identified by the respondents and those relating to education and training are set out at the end of the methodology section below. The study included a survey of the professionally qualified staff of the provincial library services of the four former provinces, the Cape, Natal, Orange Free State and Transvaal, conducted in 1994 (Stilwell 1995).

The survey which took place just prior to the general election, revealed interesting information about the views of this little researched group of LIS personnel. These findings have bearing on the education and training debates currently in progress. The findings are also significant because these services form the backbone of public library provision in the country. Together they have enormous potential to affect development in the southern African region (Stilwell 1995: 280). By 1995 the four former provincial library services served, for example, 1.512 public libraries (Comparative 
library statistics of South Africa 1995:[1]) and in KwaZulu Natal, for instance, there has been considerable expansion over the last two years. Together the provincial library services and their affiliated public libraries are the largest providers of employment in the LIS sector in South Africa (Provincial library services in momentum 1992:[3]) hence their views on education and training could be regarded as a potentially very significant lobby in determining the new framework for LIS education and training.

\section{Methodology}

The study surveyed the entire population of the professionally qualified staff of the four former provincial library services (hence the names used for these provinces prior to April 1994 are used where appropriate). This group included those who had at least a B Bibl degree (that is the four-year Bachelor's degree which includes modules comprising the basic professional qualification) or a post graduate diploma in library and information work, or their equivalent and above.

The primary methodology was the survey. Literature surveys in library and information work as well as in the related areas of political studies, sociology and psychology were undertaken. A literature review, including a content analysis of newspaper coverage, was used to establish the sociopolitical circumstances of the period and responses from the public library domain to the events of the period were identified. The overview of the provincial library services, the interpretation of the results and the conclusions drew on the literature review.

The basic purposes of the descriptive survey are usually to describe the characteristics of the population studied, estimate proportions in the population, make specific predictions and test relationships (Powell 1991:56). This type of survey was considered appropriate to the intention of the study which was to lay the groundwork, in the form of identifying categories, so that causal relationships could be assessed in future studies.

A mailed questionnaire was used because the population was dispersed through the head and regional offices of the four former provincial library services. A liaison person in each service provided contact with the staff. All the members of the population were asked the same questions so as to obtain comparable data.

Structured, semi-structured and some unstructured items (in which the respondent had freedom of response) were included in the instrument. The items were derived from the literature reviewed, consultation with some staff at the Natal Provincial Library Service (NPLS), the researcher's own experience at the NPLS in the 1970s, and the researcher's participation in library and information initiatives such as the National Education Policy Investigation and its Library and Information Service's Research Group. The items were pretested for relevance.

Analysis of the data involved coding and reducing to frequencies the responses to structured items and the scaled responses. Descriptive statistics were used and procedures suited to the manipulation of categorical data were selected. Responses to unstructured items were subjected to content analysis.

Evaluation of the research methodology revealed that the methodology employed enabled the summarization of data in elucidation of the research problem. The research instrument was appropriate in that it generated the data required for descriptive statistical analysis. The statistical analyses performed were seen as appropriate and adequate for the study.

The findings of the study revealed that the perceptions of the staff of the provincial library services indicate a need for change in response to socio-political circumstances. The study suggested that change has commenced to some extent in the provincial library services in response to the sociopolitical circumstances of the period. Suggestions that more effort and a more radical approach are needed indicate the extent of the task to be accomplished. Areas for further research activity are identified and using this study as the base, a more sensitive instrument could be designed to test causal links in a way this exploratory study could not. Further details about the study are provided in more general accounts of this research (Stilwell 1995; 1996; 1997). In this article the education-related findings are reported in some detail. The findings are given about this group of formally qualified staff concerning their educational attainment, work motivation and value clusters, their perceptions of staff selection and their views on their own competence, autonomy and influence. Staff perceptions of various avenues of education and training are examined such as affiliation to a professional organization, and in-service and continuing education and training. Training for affiliated public librarians is also addressed. The intention here is to identify and discuss the education and training issues specifically. Distinguishing between the various forms of education and training is critical to the analysis and discussion and definitions are clarified in the next section.

\section{Definitions of terms}

First professional education and training comprises the fouryear undergraduate or one-year post graduate programmes which equip the candidate with a 'professional' library and information services qualification.

\section{In-service education and training is a}

'scheme whereby trainees or the more junior members of a staff are given instruction in the routines carried out in the library and on wider and more general aspects of librarianship' (Harrods librarians glossary 1995:326).

It is training undertaken as part of equipping employees for work in a particular work organization and specific environment.

Continuing education, referred to also as continuing professional development, continuing professional education or continuing library education can be described as

'a career-long process of improving and updating skills, abilities and competencies of staff by regular 
in-service training and education, supported by external courses' (Harrods librarians glossary 1995: 164).

Kuhn (1994:48-49) refers to continuing education as the learning activities and efforts, formal and informal, by which individuals seek to upgrade their knowledge, attitudes, competencies and understanding in their special field of work to deliver quality performance in the worksetting, and enrich their library careers. She points out that continuing education comes after first professional education in the case of qualified library and information workers. It is broader than staff development and in-service training which are usually initiated by an organization for the development of its own human resources. Continuing education tends to be related to job responsibilities and content to improve competence, provide opportunities to be exposed to new ideas, to use new knowledge in the job and to grow as persons as well as library and information workers (Kuhn 1994:49). It would seem as if continuing education has a greater focus on the needs of the individual than on those of the organization (Varlejs 1987) which would be paramount in staff development and inservice training.

Staff development in Creth's 1989 definition (Callahan \& Watson 1995:376)

'encompasses a range of activities designed to provide all levels and categories of library staff professional and support staff, part-time employees, and volunteers - with the knowledge, skills and attitudes required for them to meet their current responsibilities and to adapt to future changes'.

While first professional or basic education and training, inservice and continuing education are discussed in the article, it is within the recognition suggested by the definition of continuing education above (Harrods librarians glossary $1995: 164)$ as in 'career-long', and also in the comment provided by Menou (1993:255) that

'In a discipline which is undergoing such a continuing, fast and far-reaching transformation as library and information science does, the idea that basic education can equip persons for the whole duration of their career is at least inappropriate, if not simply ridiculous ... It should be recognised that, in our field, no other option exists other than life-long education. If this is a starting point, the traditional distinction between basic and CPE [Continuing Professional Education] loses its uncertain ground'.

Having clarified the terms applied to the various forms of education and training the discussion now moves to the findings of the study.

\section{Educational attainment}

The educational profiles of the 59 respondents (from a population of 197) revealed that the highest professional qualification of $64.41 \%$ (38) of the formally qualified staff was the primary degree/post graduate diploma combination. The highest professional qualification for $47.46 \%$ (28) was the primary degree or post graduate diploma combination while its equivalent, the $\mathrm{B} \mathrm{Bibl}$ was the highest professional qualification for $16.95 \%$ (ten) of the respondents.

Over half the respondents altogether, that is $55.93 \%$ (33) had the primary degree/post graduate diploma as their first professional qualification (but not necessarily as their highest professional qualification) with $35.59 \%$ (21) holding the B Bibl. The majority of the primary degree/post graduate diploma combination was from Natal with $57.58 \%$ (19) of those with this combination from this province. Of the holders of B Bibls, 35.59\% (11) were from the Orange Free State. The popularity of the primary degree or post graduate degree could have a regional dimension, in that respondents, to the extent that this was indicated, tended to have obtained their professional qualifications in the province in which they worked. A factor was likely to be which programmes were readily available in the provinces concerned.

Of the respondents nearly a quarter, $22.03 \%$ (13) had a B Bibl Honour's degree. Only three, or $5.08 \%$ of the respondents had a Master's degree as their highest professional qualification and at that stage there were no doctoral graduates amongst the respondents. In KwaZulu Natal, for instance, this profile has changed with the acquisition of a doctorate by the Deputy Director and Head. A principal librarian and a senior librarian have obtained Master's degrees but the province has lost the services of a principal librarian with a Master's degree. ${ }^{1}$

As Underwood and Nassimbeni (1996:218-219) suggest a recent point of contention in education and training for LIS is the distinction between the types of qualification at first professional level. For the first time the technikons, through the introduction of the new National Diploma (and the proposed B Tech) are able to offer programmes leading from paraprofessional to first professional qualification level. Underwood and Nassimbeni (1996:219) suggest that it is unclear whether some employers such as universities will be willing to appoint people who have obtained the National Higher Diploma, but do not have university degrees, to professional posts. The issue of how technikon diplomates gain access to Honour's and Master's degrees has been much discussed (Dickson 1994; Horton 1993; Nassimbeni, Stilwell \& Walker 1993) and remains unresolved at present (Underwood \& Nassimbeni 1996:219).

An interesting but controversial North American angle on this issue was provided by Al Kagan, African Studies bibliographer at the University of Illinois, who made the point with regard to university education and training that the primary degree or post graduate degree is a better qualification than the $\mathrm{B} \mathrm{Bibl}$ in terms of equipping librarians for work, say, in the academic library environment (Kagan 1996). Current debates in South Africa about equating the anticipated Technikon degree, the B Tech, with the B Bibl and B degree and post graduate diploma, suggest the controversial nature of such a view. Nevertheless, for interest, the researcher investigated whether either of the two first professional qualifications (that is the $\mathrm{B} \mathrm{Bibl}$ or $\mathrm{B}$ degree and post 
graduate diploma) was more likely to be followed by further study in LIS in the provincial library service context. The data analysis revealed that, of the 16 respondents who, at the time of the survey, had achieved a higher degree, $68.75 \%$ (11) had a B Bibl background and just less than half this number, $31.25 \%$ (five) the B degree and post graduate diploma combination. However, an interesting finding was that of the three respondents who had acquired a second LIS higher degree, the Master's, all three had the B degree and post graduate diploma background. Other factors to investigate as variables would be the support and attitude to the acquisition of an Honour's, for instance, in the Orange Free State, where a high proportion of the respondents held such degrees. Of the respondents $42.86 \%$ (six) of those who had an Honour's degree in LIS were from the Free State. Of the Master's degrees noted two were from the University of Natal and one was from Aberystwyth and these persons were employed in Natal (two) and the Cape (one) respectively.

The study showed no apparent positive correlation between the level of professional attainment and rank or position above principal librarian level. Cross tabulation of the position of the respondents and his/her highest LIS qualification shows that the highest qualification, at that time, obtained at assistant director to director level, was the first professional qualification. As stated this profile has changed in KwaZulu Natal regarding the Deputy Director's post. An assistant director has also obtained an Honour's degree.

At principal librarians level, $40 \%$ (four) had Honour's degrees in LIS and this degree was held by $29.6 \%$ of the senior librarians. The best professionally qualified staff were at junior management and senior librarian levels. Although staff recruitment should take heed of potential as well as professional qualifications, presupposing staff development and continuing education programmes (International Federation of Library Associations 1993:21) these findings raise questions about the discrepancy between the professional educational attainment of senior and middle management and that of junior management and the other professionally qualified staff.

Questions about the implications of this situation are: can senior staff interact with better qualified juniors without feeling threatened: what incentives exist, for example, for further study if such endeavour does not appear to be a requisite for advancement and what does discouraging further study mean in terms of influences for future responses to change? University education and training was perceived by respondents to be an influential factor in the work environment.

What was the comparative status of the senior provincial library staff when interacting with other departments? Comments made in response to a specific question in the survey suggested that senior management needed to stand up to officials in the Provincial Administration. Would their level of professional qualification hinder them in such efforts?

Just over a quarter of the sample had obtained their first professional qualification between 1981 and 1990. This finding had implications in terms of the impact of various watershed events on the attitudes of the respondents. When asked to rank their responses concerning the impact of these events on changing their views of the role of the library service, the most recent events, those of 1990, rated most favourably, with the 1984 constitution second and the student revolts of 1976 last. In other words the responses showed a linear progression from the most favourably rated recent to the least favourably rated earliest events. Seven respondents stated that they were not employed by the provincial library services at the time of the two earliest events and were unaware of the provincial library services then. Other specifically 'library-related' events were noted, such as the Zaaiman report (1988), the launch of Library and Information Workers' Organisation (LIWO) in 1990 but also the repeal of the Group Areas Act in 1990 and the opening of access to all public libraries (Stilwell 1995:214).

With reference to the education and training institution attended, with the exception of the former Cape, well over half the respondents in each provincial library service had trained in the province in which the service was located. As university education and training was rated the second most important influence on the work of respondents, after inservice training by the provincial library services (not the provincial administration), it would seem that university education and training as an avenue of influence in the provincial library services would be well worth investigating further particularly in the light of the NQF emphasis on desired outcomes.

\section{Work motivation and value clusters}

The respondents were asked why they had become librarians. This was to ascertain, in retrospect, their expectations on commencing work in LIS as a vocation. For this article the responses reveal significant information about motivation which could assist in the selection of candidates for education and training institutions. Another question which asked why they continued working as librarians tried to establish whether expectations had been met; whether adjustments to expectations had been made and whether motivation to continue work as a librarian had been sustained. These factors were seen to bear on the respondents' capacity and ability to adjust to changing demands within the work organization. These responses could prove useful to employees and educators in identifying areas for in-service (INSET) and continuing education sessions, particularly change management. Further comment will follow on these aspects towards the end of the article.

The study explored the value system or work interface. There is a dynamic synthesis between values and work behaviour (Work values and work organizations 1995:136). Personal-organization congruence is a predictor of outcomes like job satisfaction and involvement, and organizational commitment. Hence responses to the survey were important for exploring the staying power of staff through a process of adjustment and change as the period from 1990 to date has well been. Over half the respondents $55.93 \%$ (33) gave as 
their motivation for becoming librarians their perception of the work as broadly document-, information- and mediarelated. Just over a quarter of the respondents $28.81 \%$ (17) suggested that the work was people-related with a strong service aspect. Well over three quarters of the respondents, $84.75 \%$ (50) said that they were motivated to become librarians by their perception of the work as strongly document-, information- and media-related, as well as being people- and service-related.

A degree of connectivity can be inferred from the reasons for becoming a librarian to those for continuing to be a librarian. Media-, people-relatedness and service aspects can be seen to be carried through in the following high scoring responses. Well over half the respondents $57.63 \%$ (34) claimed to continue working as librarians because they experienced fulfilment, for instance, in matching material to needs. Almost a third of the respondents $32.2 \%$ (19) continued working as librarians because they saw the work as dynamic with potential for development work, education and reconstruction. Just over a quarter of the responses $27.12 \%$ (16) noted the diversity and variety of the work.

Thapisa (1991:75) has emphasized that of particular importance in work motivation is job content: job variety, skill variety, task significance, intellectual input and autonomy. The workers' creativity should be constantly challenged to fire their motivation. The findings are positive in the survey in that well over half the respondents, $57.63 \%$ (34), reported favourably on experiencing job satisfaction, for instance, in matching materials to needs. This was the case in spite of a potential contradiction in their matching materials to needs. The potential contradiction was suggested by the finding of the survey that staff perceived problems with regard to needs assessment. Several of the methods listed as used for needs assessment were considered limited by the respondents and could then be construed to be of limited assistance in providing for an apposite match with materials.

The interest and dedication of the respondents to the kinds of issues that would 'energise, direct and sustain' (Komin 1995:141) them through a process of adjustment was suggested. They were not primarily motivated by salary or status. Both of the latter were perceived as too low, however, and require attention as the more materially based motivations are important in work motivation (Zhao 1995:118). An informal survey of library salaries in KwaZulu Natal revealed that those paid to KwaZulu Natal public library staff are low (Slater 1995) although an increase is anticipated. Respondents also raised the issue of using market-related salaries to attract appropriate staff. A payment system should be able to attract and retain qualified employees of the desired quality and quantity (Thapisa 1991:81). Zhao (1995:118) refers to the synchronization theory from the synthetic school of work motivation which argues for equal importance for both materialistic and spiritual aspects of work motivation. Both types have to be well-synchronized to ensure their efficacy. Material remuneration and status are elements in job context and the latter is as important as job content. Attention should be paid to remuneration, promotional opportunities, working conditions as well as policy and education and training of a professional nature (Thapisa 1991:75). These findings would be useful in staff motivation workshops.

Value clusters produced from listing qualities required for librarians to work successfully in the provincial library services revealed that just over two thirds of the respondents rated highly a combination of a caring attitude and commitment to the community. Rated second, from over half the respondents was a variety of interpersonal and communication factors. These findings could be useful in student selection especially for public library and resource centre situations.

\section{Staff selection}

The study argued that the capacity of the organization to respond to change would be largely influenced by the type of staff employed and this in turn depends on criteria used to select staff. The respondents were asked to give their perceptions of the criteria used for selecting staff. For this article responses to the question shed light on whether attributes and competencies valued by educators and trainers resonate with those that employers in the provincial library services are perceived to esteem.

Responses concerning staff selection in the 1994 survey were significant for the creation of categories perceived to be influential, particularly as a measure of consensus was achieved between the provinces. Qualifications scored most highly as a factor and the responses reflecting the highest qualifications of respondents support this finding up to principal librarians level. Experience, as was to be expected, was rated highly. Affirmative action was a significant factor to a quarter of the Natal and a tenth of the Cape residents and appeared not to be perceived as a criterion in the Transvaal and Orange Free State. The need to employ black librarians, however, was recognized by the respondents. Thereafter the consensus was lost to a wide spectrum of varied criteria which reflects uncertainty about actual criteria, and this point might well be one library schools need to probe. Higher scoring factors were suitability for the requirements of the post; personality; compatibility with the region or section; communication skills; willingness to work hard especially for a low salary; and language competency, especially in a local black language.

The issue of experience remains a vexed area for newly qualified librarians especially as, no matter how well designed or extensive student fieldwork is, it is not considered experience as such (Spencer 1997). Walker (1993:159-160) and Underwood and Nassimbeni (1996:220) pick up on another crucial area, the language issue. The latter point out that since 1994 eleven languages are formally and officially recognized, while the former notes that more people in South Africa speak Zulu than any other language:

'Recent figures show that, while only $8.68 \%$ of the population is English-speaking and $15.66 \%$ Afrikaans-speaking, $21.61 \%$ speak Zulu as a first 
language, $17.44 \%$ speak Xhosa and the rest speak various other African languages as their first language. It is extremely uncommon for a white librarian to help black users in their mother tongue ...' (Walker 1993:159-160).

Should library schools not be exploring means of encouraging fluency in a third language, as was the case in the 1970 s but this time with the emphasis on local black and other languages?

\section{Competence, autonomy and influence}

Concerning education and training in management, Malan (1991:121) argues the case for creative management, particularly participative management, in meeting the challenges of changing circumstances. The study suggested that there was a mismatch between awareness of participative management and the actual practise of its principles in the provincial library services.

Line and Robertson (1989:161) argue that good staff management is an even greater need in the public service than in the private sector, which can give rewards and incentives unavailable to most of the public sector:

'In their absence, job satisfaction assumes greater importance: potentially it is the most tangible reward staff can get from their work. If work is not enjoyable, challenging and even at times fun, it is sad for people and sad for the organisation' (Line \& Robertson 1989:161).

The Transvaal Provincial Administration (TPA) had committed itself to participative management (Kalley 1995:136) and the Transvaal Provincial Library Service (TPLS) had confirmed it as a principle by 1993 (Hansen 1993b:2). There was evidence of consultation with fora such as the Forum of City Librarians (Pitts 1994:21); the extent to which it had been implemented in the TPLS staff structure was not entirely clear. In the Orange Free State Schimper (1993:24) had articulated a need for a participative management approach, while in the Cape the 1992 annual report referred to the introduction of a new management system which provided for inputs from all levels of staff (Cape Provincial Library Service 1992:13).

In spite of this encouraging awareness of participative management, well over a third of the respondents, $37.29 \%$ (22), stated that their service was 76 to $100 \%$ top down in management style, with $59.32 \%$ (35) indicating that it was $51-100 \%$ top down. This factor and the respondents' emphasis on vision in management ${ }^{2}$ suggests that the burden of policy formulation was placed on senior management. While is it generally accepted that the civil service is bureaucratic (Komin 1995:157) the question to be asked is whether this top-down management style is appropriate in a library service staffed by professionally qualified staff. Are there mechanisms for guaranteeing the expression of professional competence and professional autonomy? Thapisa (1989) has argued for the exercising of similar factors in the work situations of library assistants in the United Kingdom and a strong case exists for their recognition in this professional context. Modularized short courses for middle and senior management could be instituted to address this problem.

\section{Organizational affiliation}

It is common cause that LIS organizations have a role to play in education and training (National Education Policy Investigation 1992:63; Kaniki 1997:4) which could be seen to complement that provided by employers and education and training institutions, particularly with regard to continuing education and training. Kaniki (1997:4), for instance, states 'professional organizations play or should play a key role in education ...' In the 1994 survey participation in a workrelated organization was seen as having the potential to influence perceptions of socio-political change and nonparticipation would suggest a line for further inquiry. A surprising result was that almost half, $47.46 \%$ (28), of the respondents stated that they were not involved in workrelated structures. Responses suggested that informal networking was preferred to organizational affiliation as a method of keeping up with developments in the field. This finding links with relatively high involvement (nearly a quarter of the respondents, $23.72 \%$, or 14) in the more specialized organizations which deal with the subject-specific aspects of library and information work, such as the Children's Book Forum. While there are exceptions, participation in the more specialized organizations suggests a narrowing of interests to nuts and bolts issues with little potential for exposure to macro issues.

\section{In-service education and training}

Line and Robertson (1989:162) suggest that very few libraries spend more than a small fraction of their budgets on training. Training is a crucial area in transformation as it represents an avenue of influence, particularly for the organization in terms of getting its mission and ethos across to staff and possibly even to address deficiencies in staff identified during the selection process. In the 1994 survey respondents rated the efficacy of in-service training by the provincial library services highly. Well over two thirds, $69.49 \%$ (41), of the respondents rated in-service training at $50 \%$ plus for its ability to equip staff for specific tasks. This supported the finding that the factor rated most highly for its influence on the respondents' work was the provincial library service's education and training, with university education and training placed second. Provincial Administrations continuing education and training sessions were rated last of six influences. This finding suggests the importance of future INSET endeavours by the nine post-1994 provincial library services and the potential for co-operative education and training sessions between them and the university and technikon departments. 
The respondents were asked to identify particular in-service training deficiencies. The responses divide into specific subject areas for attention and limitations such as 'not sufficiently specific' or 'there is not enough time'. Some specific subject areas identified as required were: practical management skills, communication, human relations, negotiation and consultation and service to users with little or no contact with libraries. The definition of these categories is useful for both in-service and continuing education and training and can be seen to align with the findings of the study that more appropriate management, better communication, human relations, negotiation and consultation were required to fit the services for the challenges of the transformation period in South Africa. The diversity of the balance of the responses weakened further potential grouping but included human resource development in a professional context and there was a miscellany of suggestions such as budgeting, leadership, conflict management and computer training.

Limitations noted were 'lack of time because of workload', 'no formal training for specifics, have to observe and try out' and 'staff rotation could assist training if time allowed'. These findings, however disparate, suggest specific areas for improvement for this valued form of training.

\section{Continuing education and training}

With reference to perceptions of continuing education, a surprising $45.76 \%$ (27) either did not answer or thought such sessions were unnecessary. This finding was surprising in the light of the literature urging the need for such sessions (National Education Policy Investigation 1992; International Federation of Library Associations 1993:21) and the author's personal experience in an academic department of pressure on staff from various quarters to offer such sessions. As the study showed, however, many of the respondents were unacquainted with some significant literature. Highly rated among the responses were change and/or conflict management, management of staff, planning and public administration as well as the broader purpose and functions of the library in Africa. As with in-service training these areas support the findings and confirm perceptions of change, for instance, the value placed on conflict management. Useful areas are identified for continuing education sessions but the miscellaneity of the suggestions indicate a lack of consensus in the lower scoring items. Among these were information technology, specifically database design, and training in various software packages; training in all areas, general education and updating; user and community profiling scores; communication skills; and black language skills. These suggestions reveal broad areas of need which could be starting points for discussions on education and training offerings at first professional and subsequent levels particularly if compared with the results of other investigations of requirements. Kaniki (1997:12-13), reporting on priority areas for continuing education and training, included understanding of the cultural differences of various clienteles served; managerial and political techniques such as lobbying, budgeting, and good interpersonal relationships. Instruction in information technology and specifically the use of particular software packages and training in UKMARC format (especially in view of the need to pool and network resources) were others. Searching techniques for compact disc products and instruction in the full range of aspects of use of the Internet, World Wide Web and related utilities were required.

It is interesting to note the degree of mutuality in the perception of needs in the 1994 survey and that reported by Kaniki as based on personal discussions and the published literature. Of even more consequence is the realization that much of the expertise is readily available. LIS departments identified areas in which they could offer continuing education programmes provided resources and participants were available. These were broad areas such as community information and librarianship; rural librarianship; literacy education; public librarianship, children's literature and librarianship; school librarianship and publishing. Others included more specific areas such as archives, purchasing and information management, information technology, online information retrieval, Internet navigation and training in specific software packages such as CDS/ISIS (Kaniki 1997:13). Given this capacity and the value placed on university education and training by the provincial library respondents there would seem to be very little standing in the way of some welltargeted continuing education programmes. There is always a need for the continuing review of training needs by training departments and organizations, but the LIS sector in the form of specific institutions and organizations should keep track of available experts and resource persons for running these programmes (Kaniki 1997:13).

\section{Affiliated ${ }^{3}$ public librarians and training}

Comment on the education and training needs of the affiliated public librarians came up in a priority listing of required changes. These librarians are appointed and paid by the local authority and the role of the province is to supply guidance and support. Of the respondents $8.47 \%$ (five) suggested that more effective use of resources should be achieved by appointing qualified librarians to staff community information or education and literacy centres with salaries commensurate with the skills required. Higher standards should be set for the appointment of affiliated librarians and training should be provided in conjunction with other agencies to upgrade the skills of these librarians.

Intensive retraining of librarians concerning the new South Africa was suggested as well as the need for greater commitment, efficiency and promotion of the library by public librarians. Prioritizing service to rural and disadvantaged areas was noted. A related suggestion was that more training was required for librarians in rural and 'developing' communities. The maximum number of people should be served by a service concentrating on basics and spending less on expensive window dressing - 'luxuries such as Library Week'. As noted earlier rural librarianship was one of the areas listed by Kaniki (1997:13) in which some education and 
training departments could offer expertise. In addition in KwaZulu Natal, Hart (1997:910) reports on the second of two KwaZulu Natal Library Service training workshops for public librarians attended by 150 affiliated librarians which took place in December 1996. The workshop provided a special focus on basic library training and public library promotion in particular.

\section{Current and future challenges in terms of the NQF}

Many changes are underway in the education and training sector in South Africa (Underwood \& Nassimbeni 1996) and the University of Natal, for instance, is in the throes of restructuring its existing faculties into fewer faculties comprised of schools of cognate disciplines. While this has been introduced as a measure to maximize cost effectiveness it also offers interesting enhanced opportunities to link more closely with other disciplines, for instance, in policy and development studies and research methods thus achieving the long called for multi-disciplinary approach to various offerings (Braman 1989; Fairer-Wessels \& Boon 1995; Rowlands 1996). The programmes offered by the schools of cognate disciplines will be subject to the parameters and funding criteria of the South African Qualifications Authority (SAQA) and the NQF and its system of learning outcomes.

The intention of the NQF is to bring about transformation. It attempts to move the measurement of achievement and training away from inputs and towards outcomes (South African Qualifications Authority bulletin 1997:2, 10). All Higher Education programmes will be registered with the NQF. Each qualification has to be submitted to SAQA in its present form by 31 December 1997, for recording. Thereafter such a qualification will have to be submitted to one or more National Standards Bodies for processing following a standard form description, ${ }^{4}$ within a two-year period from 1 January 1998. A transitional five-year period has been set for interim registration of the qualifications of the NQF. This period allows for qualifications which meet the minimum criteria (in the standard form description) to be phased out and to be replaced with new versions. New qualifications may also be submitted for interim registration during this period, or may, if they meet the requirements, be submitted for registration (South African Qualifications Authority bulletin 1997:17-18).

National Standards Bodies (NSBs) will determine the appropriate form of registration in terms of the use of unit standards within qualifications. It seems likely that a process will be followed that is similar to that followed in the United Kingdom to arrive at National Vocational Qualifications (NVQ); that unit standards will be derived from a process of function analysis whereby the broad functions are broken down into smaller and smaller ones until each forms a single meaningful entity. These would then be grouped in the form of standards. The standards in turn would be grouped to become units of qualifications. These would then need to be tested and amended, hence assessment and verification systems are important (Dakers 1992:5).
NSBs will also be charged with ensuring that a coherent laddered set of qualifications is developed and registered in each subject field. This is vital in professional fields such as that of library and information work where problems of articulation have often been most acute. It is imperative that the library and information sector identifies and makes known its recommendations. At the same time it is noted that programme accreditation and approval procedures are not by themselves an effective guarantee of quality (University of Natal 1996[3-4]).

The SAQA Act provides for the establishment of bodies responsible for monitoring the achievements of education providers in offering programmes that meet standards and qualifications approved by relevant National Standards Bodies. The National Commission for Higher Education (South Africa. National Commission for Higher Education 1996) believes that a Higher Education Quality Council should be the umbrella body for quality assurance in higher education with specialist bodies linked to National Standards Bodies subject fields undertaking the external evaluation function. Standards Generating Bodies will comprise key education and training stakeholders in the subfield, drawn from interest groups and specialists who have been identified by the NSB according to the requirements of SAQA. Their role will be to generate unit standards and qualifications in accordance with SAQA requirements in identified subfields and levels. They will also update and review standards and recommend unit standards and qualifications to NSBs. Education and Training Quality Assurance bodies (ETQAs) will have the task of promoting quality among constituent providers, that is the registered constituency of the ETQA. Amongst other tasks they will accredit providers in terms of quality management, monitor provision and undertake quality systems audits (South African Qualifications Authority bulletin 1997:11-13).

Quality assurance systems vary from country to country but common features include an initial self-evaluation process followed by peer review of the results and the process of evaluation. An independent body usually co-ordinates the external evaluation which is conducted in terms of more or less standard criteria ranging from detailed norms to more flexible checklists. The results of evaluation are public and negative sanctions can ensue as a consequence of the assessment procedure but with the emphasis on opportunities to address identified shortcomings rather than punitive sanctions, for instance, related to funding. A positive outcome could be a common qualification currency across all fields (University of Natal 1996[3-4]). Dakers (1994:446), however, notes the criticism with regard to Britains NVQ system that the standards are based on competence and that competence is likely to achieve adequacy rather than excellence.

The challenge for educators and trainers and practitioners will be to reach agreement on appropriate national standards for the accrediting bodies so that programmes can be recognized in terms of agreed-upon standards bearing in mind the criticism noted above. The most difficult task is likely to 
be getting a diverse range of practitioners from various library situations and the educators and trainers, again, from diverse situations to agree on the unit standards. Addressing other issues such as the range and nomenclature of LIS qualifications (Transforming our Library and Information Services. KwaZulu-Natal Translis Forum 1997:[2]) which present a problem to employees particularly in the provincial and public libraries, is likely to follow. Other crucial substantive issues likely to be resolved include mobility, horizontal (between training institutions) and vertical (Underwood \& Nassimbeni 1996:219).

Apart from the impetus such deliberations could give to formal education and training, it is very likely that the demand for continuing education will increase. The new system indicates an intention to allow recognition of prior learning achieved through formal, informal, non-formal learning and work experience (South African Qualifications Authority bulletin 1997:16). Practitioners who wish to ensure the currency of their competencies and their employability are likely to enrol for programmes that allow for such recognition and offer education and training, or updating, in areas that have become central to the field (such as information technology). One of the potential advantages of the new system is its intention to 'facilitate the international comparability of unit standards and qualifications' (South African Qualifications Authority bulletin 1997:17) which could enhance local learners' employment prospects abroad thereby increasing mobility internationally.

Menou (1993:258-259) points out with reference to basic curricula that if such curricula and syllabi with a flexible and modular structure are available, together with related packages of learning and teaching material, the effort of designing and implementing any course is significantly reduced. The production of the learning and teaching packages requires cooperation in the form of educators working jointly at the production of a particular textbook or package. It could consist simply of a system whereby the LIS community would be informed of material under preparation and avoid unnecessary duplication. One needs to note here the contribution, for instance, of Behrens (1994) with her Bibliographic control and information sources and the useful background research of Nassimbeni and others on policy for the Report of the InterMinisterial Working Group on the LIS function (South Africa. Departments of Arts, Culture, Science and Technology \& Education 1997). Menou stresses that distance education based on modern information technologies is most probably the only viable alternative for delivering adapted instruction where required but that the investment in most instances is prohibitive for single institutions. Cooperation between education and training institutions would seem to be the key note.

\section{Conclusion}

Finally, one hopes recognition will be given by educators, trainers, and employees, to Paez-Urdaneta's view (in HavardWilliams 1992:18) of the importance of the attribute of self- improvement, that is of positive motivation, firstly, and secondly, of aspects of personality such as friendliness. Walker (1993:159-160), for instance, also stresses the importance of attitudes, social skills and language sensitivity. Among the top competencies in Paez-Urdaneta's study were the ability to train others and the promotion of service. These link interestingly with the findings of this study, for instance, with the provincial library services' staff valuing INSET and their perceptions of the need to refocus and promote the service. First professional, in-service and continuing education and training all have roles to play as parts of life-long education. Suggestions about the choice of their primary focus are reviewed in this article. How these forms of education and training will dovetail needs to be addressed. It is hoped that the research reported here will add creatively to the debates on these education and training issues and their outcomes.

\section{Notes}

1. At the time of the 1994 survey the formally qualified staff would have obtained at least the first professional qualification, that is, a primary degree and post graduate diploma, or the Baccalaureus Bibliothecologiae (B Bibl). At the time no technikon-trained staff employed at this level were identified. A Librarian in the provincial library services would have professional qualifications and occupy the lowest level of professional post. In some instances a non-professional, or Library Assistant, may occupy a Librarian's post. Senior Librarians are professionals of a certain level of seniority and promotability. The Librarian and Senior Librarian ranks are interchangeable in terms of scale. Principal Librarians are appointed to specific junior management posts on the basis of their seniority as Senior Librarians and their promotability. Section Heads are usually Principal Librarians but Senior Librarians could serve as Section Heads for a short period. It is possible for a Principal Librarian in a research post, for example, not to have the duties of a Section Head. The next three levels up would be Assistant Director, then Deputy Director, and, in the case of full Directorates, as was the case in 1994, the former Transvaal and the former Cape, Director. KwaZulu Natal Provincial Library Service has since 1994 become a directorate but a Director has yet to take up the post. Posts are generally filled on the basis of rank promotions, however, when appointments are advertised outside the service other criteria could operate. The explication of these posts is based on the situation in former Natal (Gray 1995) and there could well be small regional variations, for example, the Cape tended to refer to Principal Librarians as Chief Librarians. While the researcher prefers the term library and information worker to librarian, the latter is used in this article for the sake of brevity.

2. The 1994 survey attempted to discover, from the professionally qualified librarian's point of view which competencies and attributes were most important in senior 
management. Respondents were asked to rank various competencies and attributes and also to rate a range of office bearers concerning the vision required to lead the service and with regard to the clarity of their view of the reason for the services existence. Clear vision of the way forward in senior management was rated most highly in each province, with communication skills second, determination third and administrative skills last. The most favourable rating of office bearers concerning their vision was achieved by the Head of the service in all provinces except Natal where the best rating went to Deputy Director or Assistant Director level. Concerning the clarity of the views of the office bearers about the reason for the existence of the service the Head was rated most favourably overall except in Natal where s/he was rated second. With regard to who was believed to be influential in the service regarding the formulation of policy the highest score was achieved by the Heads of the services, Natal included.

3. The public library in South Africa is funded from public monies chiefly from the rates revenue of its local authority. The provincial library services supply financial contributions towards capital costs such as buildings, and also supply library materials, and professional advice to the public libraries affiliated to them (Shillinglaw \& Thomas 1988:266). The latter are known as affiliated public libraries and those who staff them are termed affiliated public librarians.

4. The required minimum of details for the description are: the purpose of the qualification; assumptions of prior learning already in place before the programme leading to the qualification is commenced; exit level outcomes; total credits required; minimum and sometimes maximum credits required at specific levels; integrated assessment appropriately incorporated to ensure that the purpose(s) of the qualification is(are) achieved; articulation possibilities with related qualifications, either generic or specific arrangement for articulation; and moderation options (South African Qualifications Authority bulletin 1997:18). These details are described with relation to the specific meanings of the SAQA guidelines provided.

\section{References}

Braman, S. 1989. Defining information: an approach for policy makers. Telecommunications policy, 13(3):233-242.

Behrens, S.J. 1994. Bibliographic control and information sources. Second edition. Pretoria: Unisa.

Callahan, D. \& Watson, M. 1995. Care of the organization: training and development strategies. Journal of academic librarianship, 21(5):376-381.

Cape Provincial Library Service. 1992. Annual report. Cape Town: CPLS.

Comparative library statistics of South Africa. 1995. Document issued at the Library and Information Services for Developing South Africa (LISDESA) Conference, Durban, 23-26 January. Menlo Park.
Dakers, H. 1992. National Vocational Qualifications (NVQs): the impact they are likely to make on libraries and information departments, in Developing professionals in information work: personal and organisational growth in libraries, ed. L. Foreman. London: HMSO.

Dakers, H. 1994. A matter of competence. Library Association record, 96(8):446-447.

Dickson, N. 1994. Education and training for library and information services in a changing SouthAfrica. Innovation, 9:3-9.

Fairer-Wessels, F.A. \& Boon, J.A. 1995. Information management education: towards an interdisciplinary approach. South African journal of library and information science, 63(4):179-186.

Gray, M. 1995. Personal communication regarding definitions of staff posts, library depots and branch libraries. Pietermaritzburg, 12 May.

Hansen, B. 1993. Introduction, in Transvaal Provincial Library Services.1992/3. Review:2-3.

Harrods librarians' glossary. 1995. 8th edition compiled by R. Prytherch. Aldershot: Gower.

Hart, J. 1997. Workshop highlights promotion of public libraries. KZN librarian, 1(1):9-10.

Havard-Williams, P. \& Neill, R. 1993. Weighing the future: will libraries be there to be weighed? In Proceedings of the Info Africa Nova Conference, Pretoria, 3-7 May 1993, ed. A.G. Coetzer. Pretoria: Info Africa Nova: 69-89.

Horton, W.J. 1993. The structure of library education in South Africa. Journal of education for library and information science, 34(3):253-254.

International Federation of Library Associations. 1993. IFLA mission to South Africa: report. The Hague: IFLA.

Kagan, A. 1996. Personal communication regarding qualifications for librarians in academic libraries. Pietermaritzburg, 29 May.

Kalley, J. 1995. The effect of apartheid on the provision of public, provincial and community library services in South Africa with particular reference to the Transvaal. Ph D Thesis, University of Natal, Pietermaritzburg.

Kaniki, A.M. 1997. Continuing education and training programmes for library and information personnel in South Africas educational institutions. Education for information, 15(1):1-15.

Kao, H.S.R., Sinha, D. \& N. Sek-Hong. eds. 1995. Effective organizations and social values. Delhi: Sage.

Komin, S. 1995. Culture and work-related values in Thai organizations, in Effective organizations and social values, eds. H.S.R. Kao, D. Sinha \& N. Sek-Hong. Delhi: Sage:137-163.

Kuhn, R. 1994. Some notes on continuing library education (CLE) for library and information workers. Innovation, 9:48-53.

Line, M. \& Robertson, K. 1989. Staff development in libraries. British journal of academic librarianship, 4(3):161-175.

Malan, S.I. 1991. Veranderinge, innovering en vernuwing in professionale werkslewe: die uitdagings vir biblioteek- en inligtingsdiens. South African journal of library and information science, 59(2):112-122.

Menou, M. 1993. Requirements for international cooperation in continuing education for libraryand information work, in Continuing professional education and IFLA: past, present and a vision for the future, ed. B. Woolls. Munich: Saur: 253-261.

Nassimbeni, M.C., Stilwell, C. \& Walker, C. 1993. Education and training for library and information work: an analysis of the current South African situation with a view to the way forward. Innovation, 6:30-44.

National Education Policy Investigation. Library and Information Services Research Group. 1992. Library and information services: report of the NEPI-LIS Research Group: a project of the National Education Co-ordinating Committee. Cape Town: Oxford University Press/NECC. 
Pitts, C. 1994. Transvaal Provincial Library Service. Cape librarian, 38(1):19-21.

Powell, R.R. 1991. Basic research methods for librarians. 2nd ed. Norwood: Ablex.

Provincial library services in momentum. 1992. [Pretoria]:[TPLS]. Pamphlet.

Rowlands, I. 1996. Understanding information policy: concepts, frameworks and research tools. Journal of information science, 22(1):13-25.

Schimper, J.J. 1993. Libraries and a multicultural society. Free-State libraries, Jan. Mar.: 1-6.

Shillinglaw, N. \& Thomas, W. 1988. The information society. Parklands: Donker.

Slater, C. 1995. Personal communication regarding staff salaries. Pietermaritzburg, 2 May.

South Africa. National Commission on Higher Education (NCHE). 1996. Discussion document:A framework for transformation. Pretoria: NCHE.

South Africa. Departments of Arts Culture, Science and Technology (DACST) \& Education (DOE). 1997. Report of the InterMinisterial Working Group on the Library and Information Services (LIS) Function (national level). Pretoria: DACST/DOE. South African Qualifications Authority bulletin. 1997. 1(1).

Spencer, B. 1997. Personal communication regarding attributes/ competencies of library and information diplomates and graduates. Durban, June.

Stilwell, C. 1995. An analysis of staff perceptions of the structure of the provincial library servicesand their affiliated public libraries in the light of socio-political circumstances, 1990-April 1994. $\mathrm{Ph}$ D thesis. University of Natal, Pietermaritzburg.

Stilwell, C. 1996. Staff perceptions of the structure of the provincial library services in the light of socio-political circumstances: 1990-April 1994. South African journal of library and information science, 64(4):177-185.

Stilwell, C. 1997. Transformation and renewal in South Africa's provincial library services: staff perceptions of required changes. African journal of libraries, archives and information science, 7(1):1-17.
Thapisa, A. 1989. The burden of mundane tasks: library assistants' perceptions of work. British journal of academic librarianship, 5(2):95-117.

Thapisa, A. 1991. Structures, work efficiency and work motivation among librarians, in Structures and roles of national library services in an evolving Southern Africa: proceedings of the Sixth Annual Meeting of the Conference of National Librarians of South Africa, Umtata, 13-16 July 1991. Pretoria: State Library: 74-85.

Transforming our Libraries and Information Services. KwaZuluNatal Translis Forum. 1997. Minutes of the Translis Provincial Executive Committee meeting, 17 March 1997, Department of Information Studies, University of Natal, Pietermaritzburg.

Underwood, P. G. \& Nassimbeni, M.C. 1996. First steps: reconstructing library and information science education in South Africa. Education for information, 14:215-223.

University of Natal. 1996. Quality assurance workshop, 2 August. Notes. Durban: University of Natal.

Varlejs, J. 1987. Cost models for staff development in academic libraries. Journal of academic librarianship, 12(6):359-364.

Walker, C. 1993. Closing the gap in South African libraries, in Continuing professional educationand IFLA: past, present and a vision for the future, ed. B. Woolls. Munich: Saur :151-164.

Woolls, B. ed. 1993. Continuing professional education and IFLA: past, present and a visionfor the future. Munich: Saur.

Work values and work organizations: overview. 1995. In Effective organizations and social values, eds. H.S.R. Kao, D. Sinha \& N. Sek-Hong. Delhi: Sage:135-136.

Zaaiman, R.B., Roux, P.J.A. \& Rykheer, J.H. 1988. The use of libraries for the development of South Africa: final report of an investigation for the South African Institute for Librarianship and Information Science. Pretoria: Unisa. Department of Library and Information Science.

Zhao, Y.W. 1995. 'Chines' motivation theory and application in China: an overview, in Effective organizations and social values, eds. H.S.R. Kao, D. Sinha \& N. Sek-Hong. Delhi: Sage: 117134. 